\title{
Assessment of temperature changes in carcasses in the early post-mortem period using the spectrum of a thermal imaging camera
}

\author{
PIOTR LISTOS ${ }^{1}$, MAGDALENA GRYZIŃSKA ${ }^{2}$, KINGA PANASIUK-FLAK', \\ MARZANNA CIESIELKA ${ }^{3}$, GRZEGORZ TERESIŃSKI ${ }^{3}$
}

\author{
${ }^{1}$ Sub-Department of Pathomorphology and Forensic Veterinary Medicine, Faculty of Veterinary Medicine, \\ University of Life Sciences, Głęboka 30, 20-612 Lublin, Poland \\ ${ }^{2}$ Department of Biological Basis of Animal Production, Faculty of Biology, Animal Sciences and Bioeconomy, \\ University of Life Sciences in Lublin, Akademicka 13, 20-950 Lublin, Poland \\ ${ }^{3}$ Department of Forensic Medicine, Medical University of Lublin, Jaczewskiego 8b, 20-090 Lublin, Poland
}

\section{Listos P., Gryzińska M., Panasiuk-Flak K., Ciesielka M., Teresiński G. \\ Assessment of temperature changes in carcasses in the early post-mortem period using the spectrum of a thermal imaging camera}

\section{Summary}

Precise determination of the time of death of a human being or animal is extremely important for investigations by law enforcement agencies. The aim of the study was to use a thermal imaging camera for imaging of the cooling of dog carcasses in controlled conditions, as a practical application of thermal imaging in veterinary forensics for the purpose of establishing the time of death of an animal, as well as to compare the usefulness of this method with that of the currently used Henssge nomogram. A thermographic technique exploiting infrared radiation was used in the study. The research material was $10 \mathrm{dog}$ carcasses (5 female and 5 male) aged 6 to 16 years, with body weight from 23 to $36 \mathrm{~kg}$. Thermal imaging of a carcass in combination with other methods, such as measurement of internal body temperature and analysis of post-mortem changes, enables reliable determination of the time of death of an animal, which is often of fundamental importance in veterinary forensic practice.

Keywords: veterinary forensics, time of death, thermal imaging camera

Dying is the only process that affects all living beings. The cessation of heart activity is followed by characteristic signs of death, which may vary to some extent depending on the type of death. These signs are helpful in establishing the time of death. Despite numerous studies, no method has been developed to precisely determine the post-mortem interval, and this is made much more difficult by the passage of time. Within the first six hours, the margin of error is two hours, after about 14 hours it increases to three hours, and after another ten hours it is 4.5 hours.

The best methods include measurement of body temperature, usually in the rectum, and analysis of post-mortem changes such as the development of livor mortis and rigor mortis and the degree of decomposition. Biochemical and physicochemical methods may be used as well. Some researchers recommend determining the time of death using several methods simultaneously, but forensic doctors usually use the
Henssge nomogram, considered the most refined method $(7,15)$. A method of temperature measurement which has recently been the subject of great interest is thermography. This is a painless and non-invasive technique that makes it possible to visualize infrared radiation, which is invisible to the human eye. Because it is easy to use and widely available, the use of thermal imaging in medicine and related fields is continually growing. In forensic medicine, thermography can be used to measure post-mortem cooling of a body, which is important in establishing the time of death as well as for locating bodies that have been hidden, or the remains of victims of mass disasters.

Infrared radiation was used on a large scale for military purposes during WWI, and in medicine at the start of the 1970s. At that time thermography was applied to diagnose breast cancer in women, in which the temperature of diseased tissue was found to be $1-2^{\circ} \mathrm{C}$ higher $(19,23)$. However, due to the lack of standards, 
Tab. 1. Analysed cases of dogs with their breed, body weight, age, and cause of death

\begin{tabular}{|l|c|c|c|l|l|}
\hline \multicolumn{1}{|c|}{ Breed } & Age (years) & Body weight $(\mathrm{kg})$ & Sex & \multicolumn{1}{|c|}{ Cause of death } & \multicolumn{1}{c|}{ Circumstances of death } \\
\hline Mixed & 16 & 36 & M & chronic circulatory and respiratory failure & natural death \\
Labrador & 13 & 33 & M & advanced age & euthanasia \\
German Shepherd & 6 & 26 & F & acute hypovolemic shock & road accident \\
Mixed & 14 & 34 & M & chronic circulatory and respiratory failure & euthanasia \\
\hline Mixed & 15 & 36 & M & cancer & euthanasia \\
German Shepherd & 16 & 29 & F & advanced age & natural death \\
Mixed & 8 & 26 & F & acute hypovolemic shock & premedication \\
Mixed & 13 & 27 & F & chronic circulatory and respiratory failure & euthanasia \\
\hline Mixed & 14 & 29 & M & chronic circulatory and respiratory failure & euthanasia \\
Mixed & 15 & 23 & F & advanced age & natural death \\
\hline
\end{tabular}

it became only an auxiliary method. Currently, thermal imaging is used in many areas of medicine. It is increasingly applied in cardiology to evaluate circulation or to monitor vascular diseases. In otorhinolaryngology, it is used to diagnose inflammation of the paranasal sinuses and oral cavity. In allergology, it supplements standard skin tests and is helpful in diagnosing various allergies.

In veterinary medicine, thermal imaging is often used in horse breeding. Together with clinical tests, it is a tool for diagnosing musculoskeletal diseases. A thermal imaging camera has been used to examine mastitis in cows, in which the udder temperature was found to be increased by $2.3^{\circ} \mathrm{C}$. The thermal imaging method has also proven useful in zoos for monitoring wild animals; for example, it has been used to detect diseases in African elephants. In forensic medicine and veterinary forensics, thermal imaging is mainly used to investigate post-mortem cooling. This is useful in establishing an approximate time of death (13). In addition to monitoring of people and animals, thermal imaging also has wide application in construction; e.g. for inspection of thermal insulation of buildings, in energy companies for supervision of power lines and transformers, in heating systems for inspection of power boilers and waterproofing of chimneys, and by the police, border guard and army $(1,20)$.

The aim of the study was to use a thermal imaging camera for imaging of the cooling of dog carcasses in controlled conditions, as a practical application of thermal imaging in veterinary forensics for the purpose of establishing the time of death of an animal. Additional objectives were to establish temperature standards for comparative studies and to compare the usefulness of the method with that of the currently used Henssge nomogram.

\section{Material and methods}

All procedures were in compliance with ethical standards for experiments on animals. The study involved contactless estimation of the temperature of dog carcasses by remote recording of emissions of infrared radiation and transformation into a visible image. A FLIR Ex thermal imaging camera was used, with a temperature range from $-20^{\circ} \mathrm{C}$ to $650^{\circ} \mathrm{C}$ and detector resolution of $160 \times 120$ pixels. FLIR Tools software was used to analyse the measurements. Testing was carried out in a room with constant temperature $\left(19^{\circ} \mathrm{C}\right)$ and humidity $(55 \%)$.

The research material comprised ten dog (Canis lupus familiaris) carcasses. Information on the causes of death was obtained from the documentation of veterinary surgeries (Tab. 1).

The temperature distribution in the dog carcasses was evaluated three times: immediately after death, to record an image corresponding to the spectrum in the live animal; after one hour, and after 12 hours. As in the case of evaluation of the decrease in the internal temperature of a carcass, it was assumed that at one hour post-mortem the spectrum, through changes in colours, illustrates significant changes, thereby enabling estimation of the post-mortem interval. The spectrum was evaluated at $12 \mathrm{~h}$ post-mortem in order to obtain a thermal image of the dog carcasses when the temperature was similar or equal to the ambient temperature.

\section{Results and discussion}

The results indicated that the thermal images of the dog carcasses changed visibly over time. These changes were indisputably characteristic enough to enable an assessment of when the image was obtained (Fig. 1-3). The image of the spectrum is influenced by external conditions. Environmental conditions can distort the results to the extent that the image from the thermal imaging camera and its analysis will have no scientific significance. Elements near the camera that reflect the rays emitted by it, such as steel elements in the necropsy room, as well as conditions raising the temperature of the carcass, such as sunlight or an infectious disease combined with sepsis, also alter the spectrum image, thereby significantly masking the actual results. In our study, however, as the conditions in the necropsy room where the experiment was conducted were kept as constant as possible, the thermal imaging of the dog carcasses provided an actual thermal image showing the temperature distribution in different parts of the body and enabled observation of the changes in temperature over time. At $12 \mathrm{~h}$ post-mortem, the image 


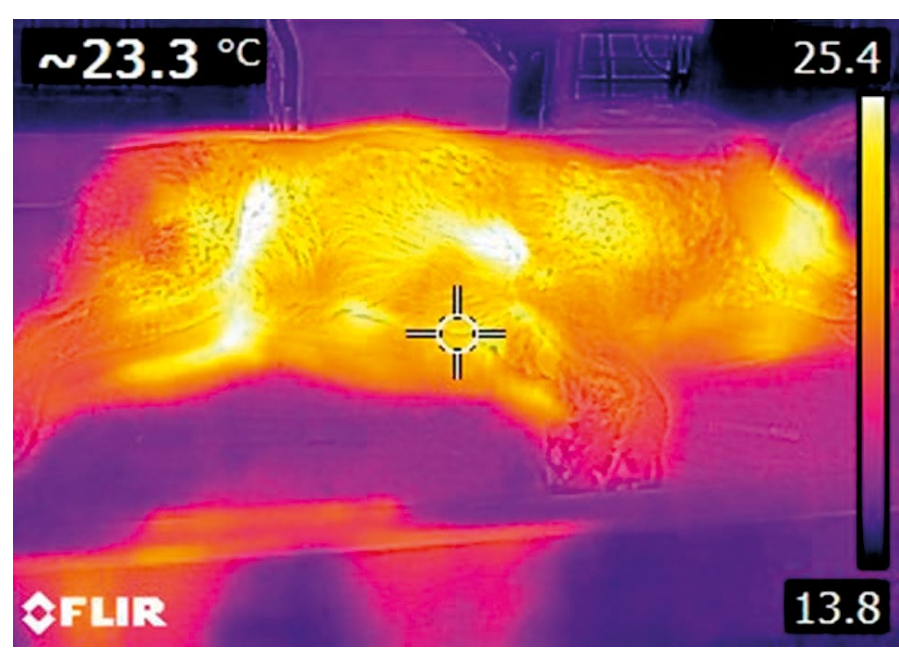

Fig. 1. Image from a thermal imaging camera immediately after death

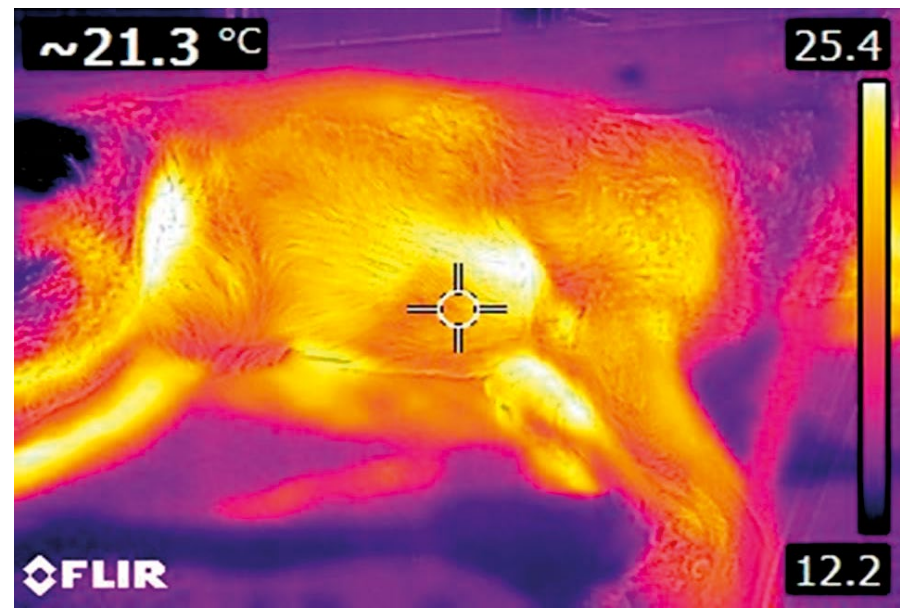

Fig. 2. Image from a thermal imaging camera at $1 \mathrm{~h}$ postmortem

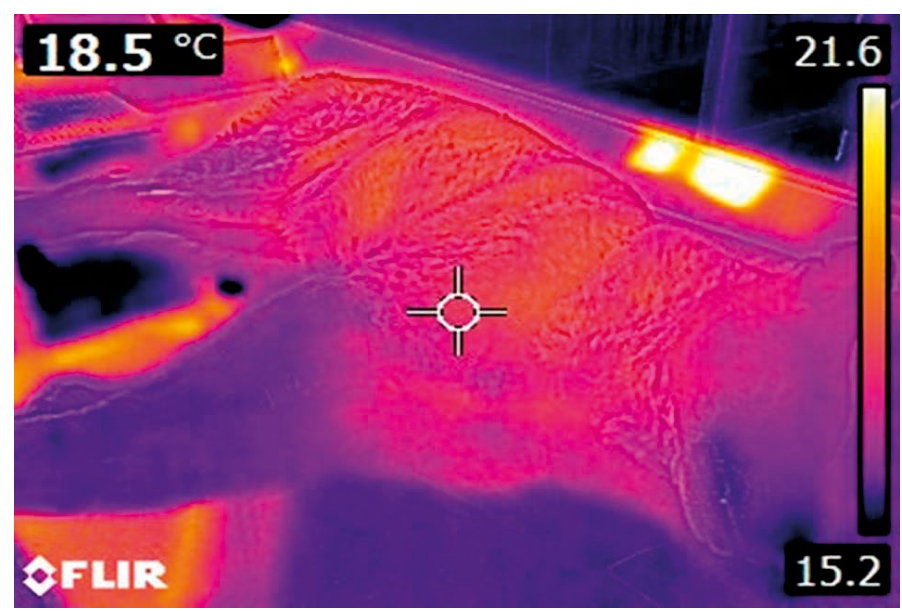

Fig. 3. Image from a thermal imaging camera at $12 \mathrm{~h}$ postmortem

obtained with the thermal imaging camera was very similar to the previous image and showed a higher temperature in the chest area than in the distal parts of the body. The combination of thermal imaging of the carcasses with other methods, such as measurement of internal body temperature or analysis of early post-mortem changes, enables a reliable determination of the time of death of an animal, which in forensic veterinary practice is often of fundamental importance.
One of the early post-mortem changes is the cooling of the body (algor mortis). When blood circulation and vital processes cease, together with the functioning of the thermoregulatory centre of the brain, the body gradually begins to cool. The rate of cooling depends on multiple factors. If death takes place in a very warm environment, the temperature of the body will rise after death (4). In the climate conditions of Poland, it takes about $16-20 \mathrm{~h}$ for the body temperature to equal the ambient temperature. This is influenced by moisture in the environment, fat tissue thickness, the surface area of the body, and clothing on the deceased.

For the first 6-9 hours post-mortem, the rectal temperature or temperature measured in the thigh muscles (following an incision), falls $0.5-1.5^{\circ} \mathrm{C}$ per hour, and then more slowly. In the course of years of research, an initial phase of slower temperature decline - the plateau - has been observed. This phenomenon was first described by Shapiro, who pointed out that the initial slower temperature drop should be taken into account in establishing the time of death (24).

The internal organs cool down much more slowly than the exposed parts of the body, which lose heat after just 1-2 hours. Sometimes, the temperature immediately after death can increase, e.g. when death is preceded by a disease accompanied by a high fever or convulsions, or an infectious disease in combination with bacteraemia or sepsis. Hutchins hypothesized that elevated temperature in the early post-mortem period is due to continuation of the metabolic activity of tissues and the activity of enteric bacteria $(8,16)$. Estimation of the degree of cooling of the body in order to determine the post-mortem interval is only approximate, as cooling begins in the period preceding the biological death of the brain, affecting small parts of the body: the nose, auricles, and fingers. In children, due to the large surface area of the body relative to its weight, cooling begins more quickly. In contrast, the bodies of obese individuals lose heat more slowly, because the fat tissue acts as an insulator $(6,9,22)$. Carcasses cool via conduction, whereby heat is absorbed by objects in contact with the body; radiation, where heat is lost in the form of infrared radiation; and convection, i.e. air movement. A body exposed to sunlight retains heat longer than one located in the shade, while wet carcasses conduct heat faster (21).

The simplest means of determining the time of death is to measure the rectal temperature and apply the following formula: $\left(37^{\circ} \mathrm{C}-\right.$ rectal temperature $)+3 \mathrm{~h}$ $=$ post-mortem interval (h). The drawback of this algorithm is the need to assume that the body temperature at the time of death was 'correct', i.e. that it was equal to the average temperature accepted as standard. Body temperature is well known to vary between individuals, and in women it is slightly higher than in men. Moreover, it changes over the course of the day, fluctuating on average within $0.5^{\circ} \mathrm{C}$ to $0.7^{\circ} \mathrm{C}$, irrespective of the ambient temperature $(5,6)$. 
In 1962, Marshall and Hoare proposed a doubleexponential model, based on the assumption that the body does not cool according to Newton's law, but somewhat more slowly. In addition, they noted that various activities connected with handling the body (e.g. turning it over, carrying it, or removing clothes) significantly interfere with heat flow, which can lead to errors in determining the time of death (2). In the late 1980s, two studies were published by the German researcher Henssge, who modified the formula of Marshall and Hoare and established statistical values for the deviation between the estimated time of death and the actual time. He and his team developed a nomogram that is still used today, making it easy to read the time of death $(3,12)$.

Owing to numerous studies on human bodies and special phantoms filled with gel, the method of estimating time of death using the nomogram has been expanded, e.g. for bodies in water. If a body in special conditions is being examined, its weight should be multiplied by a specific coefficient. In the case of a body located in dry air and wearing thick clothing, the coefficient is 1.8 , while for unclothed bodies exposed to the wind it is $0.75(3,10)$. A relatively precise method for estimating time of death is the use of the drop in temperature in the brain, especially up to $6 \mathrm{~h}$ post-mortem. The advantage of this method is that the weight of the body does not affect its temperature, but errors may be caused by head coverings or differences in the amount of hair. This type of test has not yet been conducted on dogs and is not used in veterinary jurisprudence, so it cannot be definitively concluded whether the length and thickness of the hair affect the thermal insulation of the brain $(17,18)$. Henssge and his co-workers created a nomogram for the brain based on the same principle as the nomogram for rectal temperature. They concluded that up to $6.5 \mathrm{~h}$ post-mortem the time of death can be estimated most precisely based on the temperature in the brain, while from 6.5 to $10.5 \mathrm{~h}$ the most accurate estimate is based on brain and rectal temperature, and after $10.5 \mathrm{~h}$ on rectal temperature alone $(3,10)$.

In establishing the post-mortem interval in dogs, the length and thickness of the hair are significant. The body weighs less than a human body, so it cools faster. There is little information on the practical application of thermal imaging in forensic medicine and veterinary forensics. In 2000, Kempińska-Podhorodecka et al. (13) attempted an evaluation of thermal emission of human carcasses. Their objective was to establish temperature standards and determine the time of death more accurately than current methods. They studied 20 individuals whose time of death was known, and at the same time monitored the external conditions. However, the study was terminated and the material gathered was insufficient to formulate definitive conclusions.

According to Maksymowicz et al. (19), thermal imaging analysis may not be sufficiently valuable for judicial authorities requesting expert forensic medical opinions. However, some of the factors that can interfere with thermal imaging in the case of living subjects are not present in post-mortem examinations, so paradoxically, the use of a thermal imaging camera may prove to be of practical value.

The available literature shows that most studies dealing with determination of the post-mortem interval based on body temperature concern the internal temperature of the body, while there are few studies on the use of thermal imaging.

Kaliszan and Hauser (11), in a study on pigs, showed that the time of death can be estimated most accurately based on eye temperature (up to $13 \mathrm{~h}$ post-mortem), followed by muscle and rectal temperature. When the temperature of the body is close to or equal to the ambient temperature, the rectal temperature proves most accurate. Another method that is very precise in determining the post-mortem interval in the first few hours post-mortem is measurement of the eardrum temperature. The eyes and the eardrum cool at a similar rate, without a plateau. In the first four hours after death these measurement methods can be used to estimate the time of death to within one hour. An advantage of these methods is that the rate of cooling does not depend on body weight.

Listos et al. (14) demonstrated that the average eye socket and rectal temperature in large dogs is greater than in small dogs at each time interval. Irrespective of the size of the dogs, the temperature decreased more slowly and more uniformly in the orbit than in the rectum. In another study, Listos et al. (14) compared the temperature drop in the kidneys and rectum. The average temperature in the kidneys and rectum was greater in large dogs than in small dogs at all time intervals. In both small and large dogs the average kidney temperature was higher than the rectal temperature. Only in small dogs (up to $10 \mathrm{~kg}$ ) was the plateau effect observed, up to $30 \mathrm{~min}$ post-mortem, followed by a second plateau effect 3-3.5 h post-mortem.

According to Raszeja et al. (22), the rectal and thigh muscle temperature decreases by $0.5-1.5^{\circ} \mathrm{C}$ per hour for the first six hours. After this time it falls more slowly, and the graph is similar to a sigmoid curve with a relatively linear decline. The rate of cooling is lower by $1 / 3$ in the case of a body left in a warm room or if it is clothed. Bodies exposed to wind or located in water cool more rapidly. The study showed that unclothed bodies in water lose heat twice as fast as bodies in the atmosphere at the same temperature, without wind. A similar decline in temperature was observed in the image of the spectrum of dog carcasses. The carcasses of animals with longer hair lose heat more slowly than short-haired dogs. Differences in the rate of cooling were also noted in animals with different body weights; larger dogs cool more slowly than smaller ones.

To sum up, the image of dog carcasses obtained using a thermal imaging camera makes it possible to 
assess the temperature distribution in different parts of the body at a specific time after death. The higher the temperature of the individual immediately after death, the clearer the thermal image obtained with the camera. The absolute maintenance of constant external conditions is crucial for obtaining accurate and reliable results when examining animal carcasses with a thermal imaging camera. The method of examining the spectrum of dog carcasses and the results obtained can be helpful and to some degree can be applied to other animal species. This can be an important research model (Canis lupus familiaris) whose results could be used in formulating forensic veterinary opinions.

\section{References}

1.Bauer J., Dereń E.: Standaryzacja badań termograficznych w medycynie i fizykoterapii. Acta Bio-Opt. Inform. Med. 2014, 20, 11-20.

2. Berent $J$.: Ustalanie czasu zgonu na podstawie pomiarów temperatury. Część I. Od pierwszych badań z dziewiętnastego wieku do koncepcji opartej na modelu dwuwykładniczym Marshalla-Hoare. Arch. Med. Sąd. 2005, 55, 209-214.

3. Berent J.: Ustalanie czasu zgonu na podstawie pomiarów temperatury. Część II. Wyniki badań od lat siedemdziesiątych do końca dwudziestego wieku. Arch. Med. Sad. 2006, 56, 103-109.

4. Clark M., Worrell M., Pless J.: Postmortem changes in soft tissues. CRC Press LLC 1997.

5. Dębiec-BąkA., SkrzekA.: Porównanie rozkładu temperatury powierzchniowej ciała kobiet i mężczyzn za pomoca termowizji. Acta Bio-Opt. Inform. Med. 2012, 18, 25-30.

6. DiMaio V., DiMaio D.: Medycyna sądowa. Urban\&Partner, Wrocław 2003.

7. Henssge C., Madea B.: Estimation of the time since death in the early postmortem period. Forensic Science International 2004, 144, 167-175.

8. Hutchins G.: Body temperature is elevated in the early postmortem period Hum. Pathol. 1985, 16, 560-561.

9. Jakliński A., Kobiela J., Jeagermann K., MarekZ., Tomaszewska Z., Turkowska B. Medycyna sądowa. Podręcznik dla studentów medycyny. Państwowy Zakład Wydawnictw Lekarskich, Warszawa 1983.

10. Kaliszan M.: Określanie czasu zgonu na podstawie pomiarów temperatury wybranych okolic ciała. Badania na modelu zwierzęcym. Rozprawa doktorska, Akademia Medyczna w Gdańsku 2006.
11. Kaliszan M., Hauser R.: Określanie czasu zgonu na podstawie pomiaru temperatury oka wobec innych miejsc ciała. Arch. Med. Sad. 2007, 57, 399-405.

12. Kaliszan M., Kernbach-Wighton G.: Estimation of the time of death based on the assessment of post mortem processes with emphasis on body cooling. Legal Med. 2009, 11, 111-117.

13. Kempińska-Podhorodecka A., Szydłowski Ł., Knap O., Parafiniuk M.: Zastosowanie termowizji w medycynie sądowej na przykładzie badań prowadzonych w Zakładzie Medycyny Sądowej Pomorskiej Akademii Medycznej w Szczecinie. Rocz. PAM 2007, 53, 107-112.

14. Listos P., Gryzińska M., Batkowska J.: Post-mortem decrease in temperature in the orbit of dogs for use in determining time of death. Slov. Vet. Res. 2016, $53,85-90$.

15.Listos P., Gryzińska M., Batkowska J., Dylewska M.: Temperature reduction in internal soft tissues in relation to rectal temperature in dogs in the early post-mortem period. Vet. Arh. 2018, 88, 225-234.

16.Listos P., Gryzińska M., Batkowska J., Dylewska M., Dudzińska E., Piórkowski J.: Preliminary study on the estimation of the time of death in animals based on microflora development in a dog's gastrocnemius muscle. Med. Weter. 2017, 73, 229-233.

17. Listos P., Gryzińska M., Batkowska J., Grela M., JakubczakA.: Algorithm for establishing the time of death of a dog based on temperature measurements in selected sites of the body during the early post-mortem period. Forensic Sci. Int. 2018, 289, 124-129.

18. Listos P., Gryzińska M., PiotrkowskiJ., Teresiński G., Buszewicz G., ChagowskiW. Nozdryn-Płotnicki Z., Łopuszyński W.: Post-mortem estimation of time death of dogs based on measurements of kidney temperature in comparison with rectal temperature. Acta Vet.-Beograd 2016b, 66, 76-88.

19. Maksymowicz K., Dudek K., Bauer J., Jurek T., Drozd R.: Ocena możliwości zastosowania techniki termowizyjnej w diagnostyce medyczno-sądowej. Podstawy teoretyczne. Rocz. PAM. 2007, 53, 102-106.

20. Mazur D., Herbut E., Walczak J.: Termowizja jako metoda diagnostyczna Rocz. Nauk. Zoot. 2006, 33, 171-181.

21. Pounder D. J.: Time of death. Lecture Notes. Department of Forensic Medicine, University of Dundee 1995.

22. Raszeja S., Nasiłowski W., Markiewicz J.: Medycyna sądowa. Podręcznik dla studentów. Państwowy Zakład Wydawnictw Lekarskich, Warszawa 1990.

23. Ring E. F. J.: The historical development of thermal imaging in medicine. Rheumatology (Oxford) 2004, 43, 800-802.

24. Shapiro H. A.: The postmortem temperature plateau. Am. J. Forensic Med. Pathol. 1965, 12, 137-141.

Corresponding author: Prof. dr hab. Magdalena Gryzińska, Department of Biological Basis of Animal Production, University of Life Sciences in Lublin, ul. Akademicka 13, 20-950 Lublin, Poland; e-mail: magdalena. gryzinska@up.lublin.pl 